IZA DP No. 8607

Fertility Responses of High-Skilled Native Women to Immigrant Inflows

Delia Furtado

October 2014 


\title{
Fertility Responses of High-Skilled Native Women to Immigrant Inflows
}

\author{
Delia Furtado \\ University of Connecticut \\ and IZA
}

\section{Discussion Paper No. 8607 \\ October 2014}

\author{
IZA \\ P.O. Box 7240 \\ 53072 Bonn \\ Germany \\ Phone: +49-228-3894-0 \\ Fax: +49-228-3894-180 \\ E-mail: iza@iza.org
}

Any opinions expressed here are those of the author(s) and not those of IZA. Research published in this series may include views on policy, but the institute itself takes no institutional policy positions. The IZA research network is committed to the IZA Guiding Principles of Research Integrity.

The Institute for the Study of Labor (IZA) in Bonn is a local and virtual international research center and a place of communication between science, politics and business. IZA is an independent nonprofit organization supported by Deutsche Post Foundation. The center is associated with the University of Bonn and offers a stimulating research environment through its international network, workshops and conferences, data service, project support, research visits and doctoral program. IZA engages in (i) original and internationally competitive research in all fields of labor economics, (ii) development of policy concepts, and (iii) dissemination of research results and concepts to the interested public.

IZA Discussion Papers often represent preliminary work and are circulated to encourage discussion. Citation of such a paper should account for its provisional character. A revised version may be available directly from the author. 


\section{ABSTRACT \\ Fertility Responses of High-Skilled Native Women to Immigrant Inflows ${ }^{*}$}

While there is debate regarding the magnitude of the impact, immigrant inflows are generally understood to depress wages and increase employment in immigrant-intensive sectors. In light of the over-representation of the foreign-born in the childcare industry, this paper examines whether college-educated native women respond to immigrant-induced lower cost and potentially more convenient childcare options with increased fertility. An analysis of U.S. Census data between 1980 and 2000 suggests that immigrant inflows are indeed associated with increased likelihoods of having a baby, and responses are strongest among women who are most likely to consider childcare costs when making fertility decisions - namely, married women with a graduate degree. Given that women also respond to immigrant inflows by working long hours, the paper ends with an analysis of the types of women who have stronger fertility relative to labor supply responses to immigrant-induced changes in childcare options.

JEL Classification: $\quad$ D10, F22, J13, J22, R23

Keywords: child care, fertility, immigration, labor supply

Corresponding author:

Delia Furtado

Department of Economics

University of Connecticut

365 Fairfield Way, Unit 1063

Storrs, CT 06269-1063

USA

E-mail: Delia.Furtado@uconn.edu

\footnotetext{
I am especially grateful to Heinrich Hock for the substantial contributions he made to early incarnations of this paper. The many lengthy discussions as well as the draft code he generously provided were instrumental for completing the analysis. I would also like to thank Patricia Cortes and participants in IZA's $11^{\text {th }}$ Annual Migration Meeting for the many helpful comments. The bulk of this project was completed while visiting Boston University. I would like to thank members of the BU Economics Department for their hospitality as well as the many insights they provided while I was writing this paper.
} 


\section{Introduction}

The foreign-born population of the United States has quadrupled since the passage of the Immigration and Nationality Act in 1965. Among politicians and academics, this has led to substantial interest in the socioeconomic consequences of the recent waves of immigration to the United States. Much of the existing research focuses on the potentially negative impact of immigration on the wages and employment rates of natives (Borjas 2003; Card 2001). Less attention has been paid to the potential benefits accruing to natives from immigration. This paper considers the impact of low-skilled immigrant inflows on childcare costs and examines how natives respond in terms of fertility decisions.

Decreases in the price and increases in the availability of childcare brought on by lowskilled immigration should imply reductions in the cost of childrearing. However, the theoretical impact of lower childrearing costs on childbearing is unclear given that women may respond to these lower costs by increasing labor supply (Blau and Robins 1989) instead of increasing fertility. Cortes and Tessada (2011) find that low-skilled immigration to large U.S. metropolitan areas results in increases in the number of hours worked by women at the top of the wage distribution. If these labor supply responses are sufficiently large, then immigrant-induced decreases in childcare costs may decrease the likelihood of having a second or third child. Thus, the relationship between immigrant inflows and childbearing is essentially an empirical question.

Any analysis making use of geographic variation in immigrant concentration to study immigrant impacts address the fact that immigrant location decisions are not exogenous. Even estimates from fertility models that control for city fixed effects specifications are biased upward if low-skilled immigrants have become increasingly likely to settle in cities where high-skilled nativeborn women are developing stronger preferences for large families. On the other hand, if cities with booming economies are attracting more immigrants while at the same time providing better labor market opportunities for high-skilled women, then standard estimates of the effect of immigrant 
concentration will be biased downward. To address these potential concerns, I take an instrumental variables approach, common in the immigration literature, which relies on the propensity of new entrants to locate in areas with high historical concentrations of immigrants from the same country of origin (Bartel 1989; Card 2001).

Using 1980 through 2000 U.S. Census data on U.S.-born college-educated women of childbearing age, I find that increases in the share of low skilled immigrants in a city are associated with an increased probability that women in that city have recently given birth. Instrumental variables models suggest an even stronger impact implying that immigrants are less attracted to high fertility cities. The increases in the probability of giving birth are likely to translate into increases in completed fertility given the finding that older women, who cannot easily adjust future fertility, are most influenced by immigrant inflows. Moreover, my estimates suggest an especially large impact on the decision to have more than three children.

For evidence that immigrants are impacting native fertility decisions via childcare markets, I start by showing that metropolitan areas receiving more immigrants have larger decreases in the median wages of childcare workers. Suggestive of immigrant-induced labor supply shocks, these cities also tend to have a greater share of the labor force working as childcare workers, although this latter effect is very small and not precisely estimated.

Next, I examine whether it is indeed the women that are most likely to use formal childcare options--as opposed to caring for their own children full time or using friends and family for childcare-who are most sensitive to immigrant inflows. Results suggest that women with graduate degrees are more sensitive to immigrant inflows than women with only college degrees. This points to a role played by childcare markets given that higher skilled women are less likely to live near family members and have higher opportunity costs of leaving the labor force. Interestingly, unmarried women do not at all respond to immigrant inflows by having additional children which makes sense if unmarried women are less likely to have carefully planned pregnancies. 
For further evidence that immigrants affect fertility outcomes through childcare markets, I exploit variation in the country of origin composition of immigrants in different cities in different years. Immigrants from certain countries, such as Paraguay and Cameroon, are especially likely to work in childcare while there are virtually no immigrants from countries such as Albania and Bulgaria working in this industry. I find that native-born women have strong fertility responses to immigrant inflows from "high childcare" countries and no statistically significant responses to inflows from "low childcare” countries.

As discussed above, this analysis complements a growing literature showing that women tend to work more hours in response to reduced childcare costs. While women may respond to lower childcare costs by both increasing hours at work and having an additional child, it is probably more likely that some women respond to lower childcare costs by working longer hours while others respond by having an additional child. Because some policy-makers may be focused on increasing fertility rates while others are more interested in labor market gender gaps, it may be useful to know how different types of women respond to lower childcare costs so that policies may be targeted appropriately.

To examine this issue, I start by reproducing the result in the literature that immigrant inflows tend to increase labor supply of high skilled women, especially at the top of the hours worked distribution (Cortes and Tessada 2011). I then examine the characteristics that are associated with strong fertility relative to labor supply responses to immigrant inflows. Results suggest that women with graduate degrees are relatively more likely than women with just college degrees to respond to immigrant inflows by having an additional child. Similarly, married women have stronger relative fertility responses than unmarried women.

The paper proceeds as follows. Section 2 places the analysis within the context of the literature on fertility, labor supply, and childrearing costs. A description of the data as well as the empirical model follows in Section 3. Section 4 presents baseline results while Section 5 explores the mechanisms through which immigrant inflows impact fertility decisions of natives. Section 6 
examines the types of women who are relatively more likely to respond to immigrant inflows by changing fertility decisions as opposed to labor supply decisions. Finally, Section 7 provides additional discussion and concluding remarks.

\section{Background}

The relationships between childcare costs and fertility derived from even simple models are fairly complicated (Blau and Robins 1989). A decrease in childrearing costs may increase desired fertility due to a standard price effect and increase desired labor supply by increasing the opportunity cost of time spent at home. Hasan and Zoabi (2011) present a model showing how high wage women might substitute housekeeping and babysitting services for their own time in household production thereby allowing them to increase fertility without sacrificing their careers. However, the time costs associated with childbearing, such as time spent on late night feedings, might offset the increase in desired labor supply, at least temporarily, for women who choose to have an additional child. It is also possible that the increase in desired labor supply is sufficient to induce a lower likelihood of childbearing if, for example, additional hours lead to promotions which make women rethink original plans to have a third or fourth child. Lehrer and Kawasaki (1985) suggest that when adequate childcare is not affordable, women devote all of their energy into their domestic roles, thus increasing fertility. Hence, the net effect of changes in childrearing costs on fertility is an empirical question.

A number of studies have considered the relationship between childcare subsidies and fertility. Examining a Swedish childcare subsidy reform, Mörk, Sjögren, and Svaleryd (2009) find that lower childcare costs led to higher fertility. Gonzalez (2011) also uncovers a fertility response to an unanticipated universal child benefit in Spain. It is difficult to determine whether these results extend to a U.S. context where childcare subsidies are relatively small, at least for families in the middle and upper ends of the earnings distribution. 
A handful of papers have considered the effects of childcare costs on both employment and fertility outcomes using U.S. data. Mason and Kuhlthau (1992) examine mothers' perceptions of whether the availability of child care constrained their employment and fertility decisions. Blau and Robins (1989) analyze how transitions among employment and fertility states respond to geographic variation in weekly childcare expenditures. Modeling female labor supply and fertility jointly within a dynamic model, Moffitt (1984) finds that higher wages are associated with shifts in lifetime profiles of fertility and employment. Taking a different approach, Stolzenberg and Waite (1984) examine how variation in the individual-level association between fertility and labor force participation is explained by conditions in the local childcare market. All of these studies provide results suggesting that lower childcare costs increase fertility but rely on potentially endogenous cost measures.

My analysis contributes to the childcare cost literature, but the main focus is on the effect of low-skilled immigration on fertility decisions of high-skilled native women. Despite large increases in the demand for child care in the United States over the years, there has been only a slow rise in its price (Blau 2001), which Blau (2001) attributes to a large “unexplained” increase in the supply of labor to the childcare market. Blau and Curry (2006) suggest that the large numbers of low-skilled immigrants may have contributed to this phenomenon.

Cortes (2008) shows that low-skilled immigration leads to reductions in prices of non-traded goods and services in major U.S. cities. Cortes and Tessada (2011) provide evidence that low-skilled immigration to the United States led to an increase in the hours worked among women at the top of the wage distribution. Similar conclusions have been reached for high skilled native females in Spain (Farré, Gonzalez, and Ortega 2011), Italy (Barone and Mocetti 2011), and Hong Kong (Cortes and Pan 2011). Consistent with a role played by immigrant-induced changes in childcare prices, Amuedo-Dorantes and Sevilla (2013) find that low-skilled immigrant inflows result in changes in how mothers allocate their time with their children. In areas with larger immigrant concentrations, mothers spend less time on basic childcare tasks, such as bathing and feeding, but no less time on 
stimulating educational and recreational activities. Furtado and Hock (2010) show that the correlation between fertility and labor force participation has become less negative in cities experiencing larger increases in their foreign-born populations. To my knowledge, no other paper directly examines the effect of immigrant inflows on fertility rates of native-born women.

\section{Data and Empirical Specification}

\subsection{Data}

The main sample was drawn from the U.S. Census Bureau's 1980, 1990, and 2000 public-use microdata sample (PUMS) files, while the 1970 census provided additional data used to construct the instrumental variable. All data were obtained from the Integrated Public Use Microdata Series (IPUMS), (Ruggles et al. 2010). ${ }^{1}$

The analysis focuses on low-skilled immigrants and high-skilled non-Hispanic native females of child-bearing age (age 22 to 42). Sharply differentiating immigrants and natives by skill minimizes the possibility of competition for jobs, which might directly affect female employment prospects. Analyzing non-Hispanic native females avoids non-market channels of influence, such as social norms and peer effects, which might arise from inflows of low-skilled immigrants to the United States, the bulk of whom are from Latin America and tend to have higher fertility rates. Skill classes are based on education. "Low skilled” implies having, at most, a high school degree and never having attended college, while "high skilled” refers to having completed a bachelor's degree. The native-born women who are still in school are dropped from the sample.

\footnotetext{
${ }^{1}$ I explored adding recent 2007-2011 American Community Survey (ACS) data to my sample, but results using the larger sample were typically very noisy. There are several potential explanations for this. First, when merging several years of ACS data together, the constructed share low skilled immigrant variable may be a very poor measure of immigrant concentration when women were making fertility decisions, especially those women sampled in 2007. In addition to this, the Great Recession may have induced more noise into fertility decisions which I am not able to model using existing data. Finally, the instrumental variable used in the analysis, which is constructed using 1970 immigrant distributions, is simply not very predictive of immigrant concentrations in the years 2007-2011. For all of these reasons, I decided not to include ACS data in my sample.
} 
The underlying geographic sampling units defined by the Census Bureau have changed over time. The resulting inconsistencies in the degree to which the population of a metropolitan area is covered in the microdata files makes it difficult to construct metro-level variables that are comparable across years. To reduce the potential influence of these inconsistencies on the estimates, I include in the analysis only those MSAs that have consistent codes in the IPUMS between 1970 and 2000. Even MSAs with the same codes can consist of different counties and parts of counties in different years, but counties that are in an MSA one year but not in another typically have small populations and so remaining inconsistencies are unlikely to severely bias estimates.

\subsection{Empirical Specification}

Consider a basic fixed-effects model of the impact of low-skilled immigration using pooled data from multiple Census years:

$$
Y_{i m t}=\beta_{1} L S I_{m t}+X_{i m t} \beta_{2}+\gamma_{m}+\gamma_{t}+e_{i m t}
$$

where $Y_{\text {imt }}$ is equal to one if woman $i$ living in MSA $m$ in year $t$ has a child who is less than a year of age in the household and zero otherwise. ${ }^{2}$ The share of the working age population that is lowskilled immigrant is denoted $L S I$. MSA and year fixed effects are denoted $\gamma_{m}$ and $\gamma_{t}$ respectively while $e$ is an error term. The vector of controls, $X$, includes a marriage dummy, a control for a graduate degree, race dummies, and a full set of age dummies. To measure labor market opportunities for the high skilled women in the sample, I also include the log of average yearly income among college-educated males living in the same MSA in the same year. To measure norms and preferences regarding family life, I include the proportion of the woman's age group living in her MSA in the same year that is married, the proportion black, and the proportion non-black and non-Hispanic. To minimize sampling error in constructing these variables, I use only two age groups

\footnotetext{
${ }^{2}$ A mother who has given birth in the previous year but whose baby does not reside with her will not be counted in this fertility measure. Adoptive mothers, however, are treated as if they have given birth. Despite this, I use "having given birth" and "having had a baby in the past year" interchangeably with "having a young child in the household" throughout the paper.
} 
(age 22-31 and age 32 to 42), but results are robust to constructing three age groups and not separating into age groups at all. Standard errors are clustered on MSA-year cells, but results are robust to clustering on MSAs.

Immigrant location decisions cannot be taken as exogenous even conditional on the controls used in the analysis. Immigrants may be drawn to areas with a booming labor market for low-skilled workers and shrinking market for high-skilled workers. The lower opportunity costs of time for high-skilled women may make childbearing more attractive. It is also possible that immigrants are attracted to cities with high demand for childcare workers—ie., cities with high birth rates. For both of these reasons, ordinary least squares estimates may yield upward biased estimates of the causal effect of immigration. Alternatively, immigrants may be attracted to cities with booming economies for both high skilled and low-skilled workers. If high skilled female workers are less likely to bear children when they have better labor market opportunities, then the least squares estimate of the effect of immigration will be biased toward zero. To address all of these potential concerns, I rely on an instrumental variables (IV) approach to identify the causal impact of low-skilled immigration. Instrumental variables will also address attenuation bias in the estimated $\beta$ s due to measurement error in the share foreign born variable.

The instrument is based on the propensity of new immigrants to locate in areas with a relatively large existing concentration of co-ethnics (e.g. Bartel 1989). Following a similar line of reasoning as Card (2001), Cortes (2008), and Cortes and Tessada (2011), the instrument uses historical enclaves to predict the flow of subsequent migrants across MSAs. More specifically, the instrument for $L S I$ is

$$
\mathrm{INST}_{m t}=\sum_{b} \frac{N_{m, 1970}^{b}}{N_{1970}^{b}} \times\left[N L S_{t}^{b}-N L S_{t-10}^{b}\right]
$$

For each country of birth, $b$, the first term in this equation represents the fraction of all immigrants from country $b$ living in MSA $m$ in 1970. The second term represents the net change in the number of low-skilled working age adults from country $b$ between year $t$ and the previous decade. 
Immigrants from countries listed as "unspecified" are not used in the construction of the IV. Also, I have merged several countries in order provide consistency over the different decades in the sample. Details are available upon request.

The necessary criteria for the instrument to be valid are very similar to those outlined by Cortes (2008). These are as follows: (a) the 1970 distribution of immigrants must be uncorrelated with differential changes in relative economic conditions affecting the fertility across MSAs 10 to 30 years later, and (b) differential economic changes among MSAs should not affect the overall inflow of low-skilled immigrants to the United States. Although it is impossible to test them directly, other studies have provided evidence pointing to the plausibility of these assumptions (e.g. Cortes and Tessada 2011).

\section{Descriptive Statistics and Baseline Results}

Table 1 provides descriptive statistics of the variables used in the analysis, both in total and separated by whether the percent immigrant in a person's MSA is above or below the mean in the sample. Recall that the sample consists of non-Hispanic native-born women between the ages of 22 and 42 with at least a college degree. Interestingly, the women in high percent immigrant cities are slightly less likely to have given birth in the previous year. However, this might be explained by differences in the proportion of women who are married in these two types of cities. There are also more women defined as "other race”--the bulk of whom are Asian-in high percent immigrant cities, but the means of the other variables are very similar to each other in high and low percent immigrant cities.

Table 2 presents baseline empirical results. To provide a sense for the basic cross-sectional relationship between the number of immigrants in a city and fertility, column 1 provides estimates from an ordinary least squares model with the full set of controls but without including MSA fixed effects. Estimated coefficients on the control variables imply that married women as well as women with a graduate degree are more likely to have an infant in the household. Black women are more 
likely than white women to have recently given birth, but Asian women are less likely. Women residing in richer cities, as measured by average yearly incomes of college educated males, are more likely to have recently had a baby. Women living in areas where more women of their age group are married also have higher fertility rates, even holding their own marital status constant.

The simple OLS without MSA fixed effects estimate of the immigration coefficient suggests that a ten percentage point increase in the share of low-skilled immigrants in an MSA--note that the mean percent low skilled immigrant in the sample is 8.3--is associated with only a 0.32 percentage point increase in the probability that a high skilled-native born woman has an infant in the household. Not much credence should be placed on this figure given that there may be several unobserved city-level characteristics that are both attractive to immigrants and make high skilled women prefer larger (or smaller) families. To address these city-specific time-invariant unobservables, MSA fixed effects are added in column 2. The estimated immigration coefficient is larger in this model suggesting that in the cross-section, cities that tend to have large immigrant populations also tend to have lower fertility rates. This model suggests that a ten percentage point increase in the share of low-skilled immigrants in an MSA is associated with a 0.67 percentage point increase in the probability that high skilled women in that MSA give birth.

It is useful to think about timing in these specifications. All of the variables in the models are measured in the same year, and it is impossible that the foreign-born population in a given year has a causal impact on the probability that a woman gave birth the year before. However, the fixed effects specification exploits within MSA-between decade changes in the size of the foreign-born population. While this measure changes discretely from decade to decade, the actual foreign-born population is changing continuously between decades. Therefore, for example, the 2000 foreign born population is likely a fine measure of the foreign-born population around 1997 when women were 
making pregnancy decisions about children born in the year 1999. Surely, the 2000 measure is better than the 1990 measure. $^{3}$

Estimates from the MSA fixed effects models will also be biased if there are time-varying determinants of fertility that are correlated with the number of immigrants in a city. If, for example, low-skill industries are replacing high-skill industries in a city, we may observe increases in fertility rates among high skill women alongside large immigrant inflows not because immigrants are providing inexpensive childcare but because women face lower opportunity costs of leaving the labor force to raise children. Alternatively, if immigrants tend to move to cities with booming economies for both the low-skilled and high-skilled labor force, the MSA fixed effects models will yield underestimates of the true causal impact of immigrant inflows.

Results shown in column 3 of Table 2 suggest that the second scenario is more likely. Note that the F statistic of 14.42 reveals a fairly strong first stage relationship. Tthe estimated first stage coefficient on the instrument is positive and has a p value of less than .001 . The second stage estimate suggests that a 10 percentage point increase in the share of low-skilled immigrants in a city yields a 2.9 percentage point increase in the likelihood that a high-skilled woman has a child of less than a year old in the household.

The measure of fertility used in this paper tells us whether immigrant inflows are associated with the probability of having a child at a particular time, but it is possible that large immigrant inflows change the timing of births without changing completed fertility. Because my identification strategy relies on cross-decade changes, and a woman's births typically do not fall neatly towards the end of any particular decade, it would be difficult to interpret results of models with total number of children in the household as the dependent variable. To learn something about whether immigrant inflows are likely to impact completed fertility, I interact the percent immigrant variable with several age group dummy variables. The first column of Table 3 shows that it is women above the age of 36

\footnotetext{
${ }^{3}$ It is possible to get yearly estimates of the foreign-born population from the Current Population Survey for years following 1994 but not before that.
} 
whose fertility rates are most sensitive to immigrant inflows. Given that the oldest women in the sample cannot decrease future fertility to compensate for increases in current fertility, it seems likely that when women face immigrant-induced lower childcare costs, they do increase completed fertility.

I also examine whether immigrant inflows have the greatest impact on the decision to have a first, second, or higher order child. The second column in of Table 3 shows results when the sample is limited to women with either zero or one child in the household, column 3 limits the sample to women with one or two children, column 4 two or three children, and column 5 three or more children. Although coefficients are not always statistically different from zero, the point estimates suggest that women are most responsive to immigrant inflows when deciding to have higher order births. In fact, the effect on the decision to have a third child is more than double than the effect on the decision to have a first child.

\section{Mechanisms}

\subsection{An Analysis of Childcare Labor Markets}

The baseline estimates show that high skilled women respond to immigrant inflows by increasing fertility. However, even if the estimates can be interpreted as causal, they do not guarantee that immigrants affect fertility outcomes through childcare markets. As a first step towards showing that immigrants are in fact affecting fertility through childcare costs, I examine whether immigrant inflows lead to decreases in childcare costs as measured by wages of childcare workers. The wage bill accounts for between $60 \%$ and $70 \%$ of the operating expenses at formal and home-based childcare centers (Blau and Mocan 2002; Helburn and Howes 1996), and likely represents an even higher share of the final costs of informal childcare providers. Thus, it seems reasonable to use wages of childcare workers as a measure of the price of childcare.

Consider a basic fixed-effects model of the impact of low-skilled immigration again using pooled data from multiple Census years: 


$$
w_{m t}=\alpha_{1} L S I_{m t}+\alpha_{2} \text { Income }_{m t}+\mu_{m}+\mu_{t}+\varepsilon_{m t}
$$

The dependent variable $w_{m t}$ is the log of the median hourly wage childcare workers (both natives and immigrants) in metropolitan area $m$ in year $t$. The variable Income $e_{t t}$ denotes the log of income per capita among working-age male college graduates. ${ }^{4}$ The other variables are defined as in equation (1). Regressions are estimated using the number of high-skilled women in the MSA-year as weights. Again, I keep only MSAs that are coded in the same way by the IPUMS between 1970 and 2000.

Table 4 presents results. All estimates are constructed using the Card (2001) instrumental variables (IV) strategy described above. The estimated coefficient of -3.67 represents the percentage change in the median wage of childcare workers caused by a one percent point increase in the size of the low-skilled immigrant population. This estimate is considerably larger than most existing estimates of the wage effects of low-skilled immigration (Friedberg and Hunt 1995; Card 2001). However, much of this research is based on examining broad skill classes, rather than specific occupations. Childcare in particular is very labor intensive, as compared with the larger low-skilled labor market, providing little room for capital adjustments. Although statistically insignificant and very small in magnitude, the point estimate in the second column of Table 4 indicates that lowskilled immigration resulted in expansions in the share of the local workforce concentrated in the childcare occupation. This is certainly suggestive of a labor supply, as opposed to demand, shock.

Beyond effects on the childcare industry, low skilled immigrant inflows might impact other sectors that provide substitutes for maternal care. The remaining columns of Table 4 show the effects of low-skilled immigration on the wages and the share of the labor force working as housekeepers and food preparation workers. While the signs of the estimated coefficients are negative, immigrant

\footnotetext{
${ }^{4}$ College graduates are likely to be high demanders of household services and, for the most part, will have incomes that are not directly tied to wages in low-skill services markets. Females are not included in the income measure since their labor supply and earnings might be directly affected by wages of childcare workers. To account for top-coding, which was only an issue in 1980, I impute values for individuals whose income had been top-coded using a region-specific Pareto extrapolation.
} 
inflows do not appear to significantly affect wages in these sectors, although they are associated with increases in the share of the labor force working in food services. To summarize, the evidence suggests that immigrant inflows do represent labor supply shocks to the childcare sector. Wages of childcare workers decrease in response to more foreign born workers in a city implying that childcare costs faced by high skilled women who purchase childcare in the market are lower.

One remaining potential concern with this analysis is that educated and high-income women demand a higher quality of care (Blau and Hagy 1998; Hotz and Kilburn 1991). If low-skilled immigrants provide low quality care, then low-skilled immigrant inflows might not affect the cost of the childcare services actually purchased by college-educated women. To my knowledge, data linking the characteristics of childcare workers to characteristics of mothers do not exist. However, Blau and Mocan (2002) provide evidence that the cost of child care is a positive function of the underlying objectively-assessed quality. Thus, we can draw inference on immigration's impact on the cost of services of various levels of quality by examining the effects of immigration on various quantiles of the childcare wage distribution. If immigrants generally provide low-quality care, then we would expect them to have the strongest impacts at lower ends of the childcare wage distribution. Conversely, if they generally provide high quality care, then we would expect the largest impacts to be at the top of the wage distribution.

Table A1 in Appendix 1 shows that immigrant inflows impact wages at the bottom of the distribution more than wages at the top of the childcare wage distribution. However, one percentage point increase in the immigrant share results in a 2.35 percent decrease in wages even at the $25^{\text {th }}$ percentile of the wage distribution. This suggests that low-skilled immigrant inflows impact childcare markets across the quality distribution. Interestingly, low skilled immigrant inflows impact wages of housekeepers at the top and bottom ends of the wage 
distribution but not the middle. Immigrant inflows do not impact wages of food preparation workers across the wage distribution.

\subsection{Heterogeneous Impacts of Immigrant Inflows on Fertility}

For further evidence that immigrant inflows are impacting native fertility rates through childcare costs, I consider whether the types of women who are likely to be more sensitive to changes in childcare costs are in fact more responsive to immigrant inflows when making fertility decisions. The first two columns of Table 5 allow us to compare immigration impacts on women with a graduate degree to women with just a college degree. While the more highly educated will tend to have higher household incomes and so may be less sensitive to changes in childcare costs, they are also more likely to work long hours and less likely to live around family members making them more dependent on nannies and other non-family full-time childcare providers for the care of their children. If these high-skilled women are more likely to work in jobs that often require unplanned late nights at the office (and have husbands with similar types of jobs), they may be especially likely to use nannies, who are often foreign-born, as opposed to formal childcare centers. Results shown in the first two columns of Table 5 suggest that indeed fertility rates of women with graduate degrees are more responsive to immigrant inflows than fertility rates of women with just college degrees. ${ }^{5}$

The following two columns of Table 5 present estimates of immigrant impacts on samples of married women and unmarried women. Results suggest that the paper's main results are driven by married women; the point estimate constructed using the unmarried sample is a fairly precise zero. If unmarried women are less likely to plan their pregnancies, it makes sense that they would be less

\footnotetext{
${ }^{5}$ I only include women with a college degree in the main sample out of concern that immigrant inflows directly impact the wages and types of jobs available to low skilled native-born women. Since college educated women are not easily substituted with low skilled immigrant labor, I feel more comfortable in arguing that the main effect of immigration on these women operates through childcare markets. Nevertheless, in Appendix Table A2 I also compare impacts for women with less than a college degree. Notice that immigrant inflows impact women with at most some college completed. They have no impact on the fertility decisions of women with a high school degree or less.
} 
sensitive to changes in childcare costs. For completeness, Columns 5 through 7 of Table 5 present estimates of immigrant impacts constructed from samples separated by race. Results suggest that it is only white women's fertility patterns that change in response to immigrant inflows.

For further evidence that this analysis is measuring the impact of immigrant inflows via childcare markets, I exploit the fact that immigrants from certain countries are substantially more likely to work as childcare providers than immigrants from other countries. As a first step, I use 1990 Census data to construct the proportion of immigrants from each country that list childcare as their occupation in the Census. I define as "high childcare" those origin countries in the top quartile of the share in childcare distribution (not weighted by the number of immigrants in each group). All other origin countries are defined as "low childcare". ${ }^{6}$ I then run a regression substituting the "share working age low skilled immigrant' variable with two variables: "share working age low skilled immigrants from high childcare countries” and the corresponding share from low childcare countries. To instrument for these two variables, I use the original instrument structure but construct one IV using only the high childcare countries and the other one using only the low childcare countries. Regression results are shown in column 8 of Table 5. While immigrant inflows from high childcare countries increase fertility rates of high skilled native women, immigrants from low childcare countries have no statistically significant impact on birth rates.

\section{Labor Supply Responses to Immigrant Inflows}

While this paper presents evidence suggesting that high-skilled native born women respond to immigrant inflows by increasing fertility, there is also a growing literature showing that women respond to immigrant inflows by increasing labor supply (Cortes and Pan 2013; Cortes and Tessada 2011; Barone and Mocetti 2011; and Farre et al. 2011)). It is possible that with lower childcare costs,

\footnotetext{
${ }^{6}$ Proportions were constructed using data on immigrants in the labor force. A list of countries in each of the categories is provided in Appendix Table 3.
} 
women can both have more children and work long hours. In fact, Furtado and Hock (2009) show that immigration to an MSA results in a less negative correlation between fertility and labor force participation in that MSA. However, it might be more likely that some women respond to lower childcare costs by working more hours and not changing or even decreasing their desired number of children while other women respond with increases in fertility even if it comes at the expense of working long hours in the labor market, at least temporarily.

To examine this, I start by reproducing the general labor supply results from the literature using my data and basic empirical specification. The first column of Table 6 shows the impact of immigrant inflows on the probability of working more than zero hours in a typical week. Column 2 shows the impact on the probability of working 35 hours or more, column 3 the impact on 40 or more hours, and column 4 the impact on 50 or more hours. Consistent with the findings in Cortes and Tessada (2011), the largest effects are on labor supply at the high end of the hours of work distribution. Interestingly, immigrant inflows tend to decrease the probability of working more than zero hours in a typical week. ${ }^{7}$ Although this pattern may be surprising, it is consistent with a story whereby mothers of very young children temporarily exit the labor force to care for children but upon returning to the work force, work very long hours. For the remainder of the analysis, I focus my study of labor supply on the decision to work more than 50 hours in a typical week.

To learn more about the types of women that are relatively more likely to respond to changes in childcare costs by adjusting desired fertility relatively more than labor supply, I separate the sample by female characteristics and then compare the ratio of the estimated immigrant share coefficient in the fertility model to the estimated immigrant share coefficient in the labor supply model across characteristics. I start by comparing women with graduate degrees to women with just a college degree. The first and third columns of Table 7 simply reproduce results from Table 5 showing that the more highly skilled women are more likely to give birth in response to immigrant

\footnotetext{
${ }^{7}$ Cortes and Tessada (2011) estimate negative but statistically insignificant effects of immigrant-induced increases in the low-skilled labor force on labor force participation.
} 
inflows than the less skilled women. The second and fourth columns show labor supply responses for these two groups. Again, when considering the probability of working more than 50 hours a week, women with graduate degrees are more sensitive to immigrant inflows than women with just a college degree. While the increase in the probability of working long hours is larger than the increase in the probability of giving birth for both groups of women, if we consider the ratio of the estimated immigrant inflow coefficients and compare this ratio across the two groups, the relative fertility response is stronger for women with graduate degrees $(.68>.24)$. It should be noted, however, that although both groups of women are about equally likely to have given birth in the previous year, Table 7 shows that women with graduate degrees are significantly more likely to work long hours. If before taking the ratio of coefficients, we divide the fertility coefficient by the proportion of women with a small child in the home and divide the labor supply coefficient by the proportion of women who work more than 50 hours, the relative fertility response to immigrant inflows is significantly stronger for women with a graduate degree than women with just a college degree $(1.06>.53)$.

Next, I compare fertility relative to labor supply responses of married and unmarried women. A natural prediction is that married women are relatively more likely to respond to lower childcare costs by having a child. This is especially likely given the evidence that on average, unmarried women do not at all increase fertility as a result of immigrant inflows (Table 5). The findings presented in Table 8 show that while married women respond to immigrant inflows by increasing the likelihood of having a child and working more than 50 hours a week by about equal amounts, unmarried women have very strong labor supply impacts but no fertility impacts. The ratio of the immigration coefficients, therefore, clearly point to stronger fertility responses of unmarried women to immigrant inflows. The difference between the two groups, however, is not as stark when estimated coefficients are weighted by the means of the dependent variables. 


\section{Conclusion}

This paper builds on a growing body of work highlighting the potentially beneficial effects that immigration has on natives (Cortes 2008; Cortes and Pan 2013; Cortes and Tessada 2011; Barone and Mocetti 2011; Farre et al. 2011). In order to isolate a causal impact of immigration, I relied on a common instrumental variables approach to account for the simultaneity of the location decisions of new migrants with respect to local labor market conditions. Using settlement patterns predicted from historical enclaves as instruments, it was found that low-skilled immigration to the United States between 1980 and 2000 led to substantial reductions in the cost of market-provided child care. I found that high-skilled native-born women responded with increases in fertility.

The popular press has raised concerns about the so-called “Opt-out Revolution” (Belkin 2003; Wallis 2004) and women still being unable to "Have it All” (Slaughter 2012). These articles suggest that combining work and family responsibilities remains very difficult for women on the career track. By contrast, Goldin's (2004) assessment of detailed cohort data showed that, relative to older cohorts, women graduating from college in the 1980s have been significantly better able to combine both career and family. This paper suggests that women are in fact facing smaller tradeoffs when making fertility and labor supply decisions, and that this has, in part, been driven by the continuing flow of low-skilled immigrant workers into the United States.

The results in this paper suggest that married women with graduate degrees have more constrained fertility choices than labor supply choices, at least when compared to other groups of women. If these women are also more likely to hit the glass ceiling in their career paths, then this analysis provides a potential explanation for women's continued under-representation in top positions in business and academia despite the many new family friendly policies over the years. While policies that make it easier to combine work and family (such as subsidized childcare) do tend to increase the amount of time women spend working in the labor market, they also tend to increase the likelihood of having more children. In fact, the analysis in this paper suggests that the very 
women who are most likely to break the glass ceiling are the ones whose fertility decisions are most likely to respond to changes in childcare costs, at least the changes induced by immigrant inflows. 


\section{References}

Amuedo-Dorantes, Catalina and Almudena Sevilla. 2013. “Low-Skilled Immigration and Parenting Investments of College-Educated Mothers in the United States: Evidence from Time-Use Data.” IZA Discussion Papers 7501, Institute for the Study of Labor (IZA).

Barone, Guglielmo and Sauro Mocetti. 2011. "With a little help from abroad: The effect of lowskilled immigration on the female labour supply,” Labour Economics 18(5): 664-675.

Bartel, Ann P. 1989. “Where Do the New U.S. Immigrants Live?” Journal of Labor Economics 7(4): 371-91.

Belkin, Lisa. 2003. “The Opt-Out Revolution.” New York Times Sunday Magazine, October 26.

Blau, David M., 2001. The Child Care Problem: An Economic Analysis. New York: Russell Sage Foundation.

Blau, David \& Currie, Janet, 2006. "Pre-School, Day Care, and After-School Care: Who's Minding the Kids?" Handbook of the Economics of Education, Elsevier.

Blau, David M., and Alison P. Hagy. 1998. “The Demand for Quality in Child Care.” Journal of Political Economy 106(1): 104-146.

Blau, David M., and H. Naci Mocan. 2002. “The Supply of Quality in Child Care Centers.” Review of Economics and Statistics 84(3): 483-496.

Blau, David M., and Philip K. Robins. 1989. "Fertility, Employment, and Child-Care Costs.” Demography 26(2): 287-299.

Blundell, Richard W. and James L. Powell. 2004. "Endogeneity in Semiparametric Binary Response Models.” Review of Economic Studies 71(3): 655-679.

Borjas, George J. 2003. “The Labor Demand Curve is Downward Sloping: Reexamining the Impact of Immigration on the Labor Market.” Quarterly Journal of Economics 118(4): 1335-1374.

Card, David. 2001. "Immigrant Inflows, Native Outflows, and the Local Labor Market Impacts of Higher Immigration.” Journal of Labor Economics 19(1): 22-64.

Connelly, Rachel. (1992). “The Effect of Child Care Costs on Married Women's Labor Force Participation.” Review of Economics and Statistics 74(1): 83-90.

Cortes, Patricia. 2008. "The Effect of Low-Skilled Immigration on U.S. Prices: Evidence from CPI Data.” Journal of Political Economy 114(3): 381-422.

Cortes, Patricia and Jessica Pan. 2013. "Outsourcing Household Production: The Demand for Foreign Domestic Helpers and Native Labor Supply in Hong Kong.” Journal of Labor Economics: 31(2): 327-371.

Cortes, Patricia, and Jose Tessada. 2011. "Low-Skilled Immigration and the Labor Supply of Highly Educated Women.” American Economic Journal: Applied Economics 3(3): 88-123. 
Farré, Lídia, Libertad Gonzalez, and Francesc Ortega. 2009. “Immigration, Family Responsibilities and the Labor Supply of Skilled Native Women.” Discussion Paper 4265. Institute for the Study of Labor (IZA).

Furtado, Delia, and Heinrich Hock. 2010. "Low-Skilled Immigration and Work-Fertility Tradeoffs Among High-Skilled US Natives.” American Economic Review 100(2): 224-228.

Friedberg, Rachel and Jennifer Hunt. 1995. "The Impact of Immigrants on Host Country Wages, Employment and Growth.” Journal of Economic Perspectives 9(2): 23-44.

Gonzalez, Libertad. 2011. “The Effect of a Universal Child Benefit on Conceptions, Abortions, and Early Maternal Labor Supply.” American Economic Journal: Economic Policy 5(3): 160-188

Hazan, Moshe and Hosny Zoabi. 2011. “Do Highly Educated Women Choose Smaller Families?” CEPR Discussion Papers 8590, C.E.P.R. Discussion Papers.

Helburn, Suzanne W., and Carollee Howes. 1996. "Child Care Cost and Quality.” The Future of Children 6(2): 62-82

Hotz, V. Joseph, and M. Rebecca Kilburn. 1991. "The Demand for Child Care and Child Care Costs: Should We Ignore Families with Non-Working Mothers?” Discussion Paper 91-11. Population Research Center, University of Chicago.

Lehrer, Evelyn L., and Seiichi Kawasaki. 1985. "Child Care Arrangements and Fertility: An Analysis of Two-Earner Households.” Demography 22(4): 499-513.

Mason, Karen Oppenheim and Karent Kuhithau. 1992. "The Perceived Impact of Child Care Costs on Women’s Labor Supply and Fertility.” Demography 29(4): 523-43.

Moffitt, Robert. 1984. "Profiles of Fertility, Labour Supply and Wages of Married Women: A Complete Life-Cycle Model.” Review of Economic Studies, 51(2): 263-78.

Mörk, Eva, Anna Sjögren, and Helena Svaleryd. 2009. “Cheaper Child Care, More Children.” Working Paper 782. Research Institute of Industrial Economics.

Ruggles, Steven, J. Trent Alexander, Katie Genadek, Ronald Goeken, Matthew B. Schroeder, and Matthew Sobek. 2010. Integrated Public Use Microdata Series: Version 5.0 [Machine-readable database]. Minneapolis: University of Minnesota.

Slaughter, Ann-Marie. 2012. "Why Women Still Can’t Have it All.” The Atlantic. July/August.

Stolzenberg, Ross M and Linda J. Waite. 1984. "Local Labor Markets, Children and Labor Force Participation of Wives.” Demography 21(2): 157-170.

Wallis, Claudia. 2004. “The Case for Staying Home.” Time, March 22. 
$\underline{\text { Table 1: Descriptive Statistics }}$

\begin{tabular}{|c|c|c|c|c|c|c|}
\hline & \multicolumn{2}{|c|}{ Total } & \multicolumn{2}{|c|}{ Low Percent Immigrant } & \multicolumn{2}{|c|}{ High Percent Immigrant } \\
\hline & Mean & $\mathrm{SD}$ & Mean & SD & Mean & SD \\
\hline Child & 0.072 & 0.259 & 0.075 & 0.264 & 0.068 & 0.251 \\
\hline Share Working Age Low-Skilled Immigrant & 0.083 & 0.075 & 0.036 & 0.021 & 0.161 & 0.068 \\
\hline Age & 32.322 & 5.666 & 32.228 & 5.663 & 32.478 & 5.667 \\
\hline Graduate Degree & 0.284 & 0.451 & 0.275 & 0.446 & 0.299 & 0.458 \\
\hline Married & 0.601 & 0.49 & 0.63 & 0.483 & 0.553 & 0.497 \\
\hline Black & 0.09 & 0.287 & 0.089 & 0.285 & 0.092 & 0.288 \\
\hline Other Race & 0.019 & 0.138 & 0.009 & 0.093 & 0.037 & 0.19 \\
\hline Log Mean Income of College Educated Males & 10.771 & 0.481 & 10.692 & 0.462 & 10.902 & 0.484 \\
\hline Proportion Married in Age Group, MSA, Year & 0.601 & 0.134 & 0.63 & 0.116 & 0.553 & 0.147 \\
\hline Proportion Black in Age Group, MSA, Year & 0.09 & 0.061 & 0.089 & 0.069 & 0.092 & 0.047 \\
\hline Proportion Other Race in Age Group, MSA, Year & 0.019 & 0.048 & 0.009 & 0.009 & 0.037 & 0.073 \\
\hline
\end{tabular}

Notes: The variable "Child" takes the value one when a woman has a child of less than one year of age residing in the household. The variable "Other Race" is equal to one if the person is non-white, non-black, and non-Hispanic. The low percent immigrant sample includes people residing in MSAs where the fraction foreign born is below the mean for the entire sample. The high percent immigrant sample includes people residing in MSAs where the fraction foreign born is at or above the mean for the entire sample. The "Share Working Age Low-Skilled Immigrant" and "Log Mean Income of College Educated Males" variables constructed by MSA and year. The "Proportion Married," "Proportion Black," and "Proportion Other Race" are constructed by MSA, year, and age group. The two age groups are 22-31 and 32-42. Means are weighted by Census-provided person weights. 
Table 2: Baseline Regressions

\begin{tabular}{lccc}
\hline DEPENDENT VARIABLE: CHILD & OLS & OLS & IV \\
\cline { 2 - 4 } & 1 & 2 & 3 \\
\hline \hline Share Working Age Low-Skilled Immigrant & $0.032^{* * *}$ & $0.067^{* * *}$ & $0.285^{* *}$ \\
& $(0.010)$ & $(0.025)$ & $(0.134)$ \\
Graduate Degree & $0.005^{* * *}$ & $0.005^{* * *}$ & $0.005^{* * *}$ \\
& $(0.001)$ & $(0.001)$ & $(0.001)$ \\
Married & $0.115^{* * *}$ & $0.115^{* * *}$ & $0.115^{* * *}$ \\
& $(0.001)$ & $(0.001)$ & $(0.001)$ \\
Black & $0.004^{* * *}$ & $0.004^{* * *}$ & $0.004^{* * *}$ \\
& $(0.001)$ & $(0.001)$ & $(0.001)$ \\
Other Race & $-0.005^{* *}$ & $-0.005^{* *}$ & $-0.005^{* *}$ \\
& $(0.002)$ & $(0.002)$ & $(0.002)$ \\
Log Mean Income of Males with College & $0.015^{* * *}$ & 0.017 & -0.003 \\
$\quad$ Degree & $(0.005)$ & $(0.014)$ & $(0.016)$ \\
Proportion Married in Age Group, & $0.072^{* * *}$ & $0.157^{* * *}$ & $0.164 * * *$ \\
$\quad$ MSA, Year & $(0.010)$ & $(0.018)$ & $(0.019)$ \\
Proportion Black in Age Group, & $-0.024^{* *}$ & $0.120^{* * *}$ & 0.069 \\
$\quad$ MSA, Year & $(0.011)$ & $(0.042)$ & $(0.049)$ \\
Proportion Other Race in Age Group, & $-0.017^{*}$ & $-0.388^{* * *}$ & $-0.454^{* * *}$ \\
$\quad$ MSA, Year & $(0.010)$ & $(0.092)$ & $(0.109)$ \\
& & & \\
Age Fixed Effects & Yes & Yes & Yes \\
Year Fixed Effects & Yes & Yes & Yes \\
MSA Fixed Effects & No & Yes & Yes \\
First Stage F (excluded instrument) & 607,790 & 607,790 & 607,790 \\
N & $* * * \mathrm{p}^{*} 0.01, * * \mathrm{p}<0.05, *$ & $\mathrm{p}<0.10$ \\
Notes: Standard errors clustered by MSA and year. & &
\end{tabular}


Table 3: 2SLS Regressions by Age and Parity

\begin{tabular}{|c|c|c|c|c|c|}
\hline DEPENDENT VARIABLE: CHILD & Full Sample & $\begin{array}{l}0 \text { vs } 1 \\
\text { child }\end{array}$ & $\begin{array}{c}1 \text { vs } 2 \\
\text { children }\end{array}$ & $\begin{array}{l}2 \text { vs } 3 \\
\text { children }\end{array}$ & $\begin{array}{c}3+ \\
\text { children }\end{array}$ \\
\hline & 1 & 2 & 3 & & \\
\hline \multirow[t]{2}{*}{ Share Working Age Low-Skilled Immigrant } & 0.104 & $0.135^{*}$ & 0.166 & $0.346 * *$ & 0.495 \\
\hline & $(0.098)$ & $(0.077)$ & $(0.152)$ & $(0.165)$ & $(0.307)$ \\
\hline Share Working Age Low-Skilled Immigrant X & -0.003 & & & & \\
\hline Age 29 to 35 & $(0.017)$ & & & & \\
\hline Share Working Age Low-Skilled Immigrant X & $0.145^{* * *}$ & & & & \\
\hline Age $36+$ & $(0.015)$ & & & & \\
\hline Mean of the Dependent Variable & 0.072 & 0.047 & 0.158 & 0.133 & 0.147 \\
\hline $\mathrm{N}$ & 607,790 & 424,677 & 228,784 & 169,833 & 57,542 \\
\hline
\end{tabular}

Notes: The second column shows results of regressions conducted on a sample with either zero or one child, the third column uses a sample of one or two children, the third column two or three children, and the last column three or more children. Standard errors clustered by MSA and year. All regressions include the full set of controls shown in Table 2 including MSA, year, and age fixed effects. ${ }^{* * *} \mathrm{p}<0.01,{ }^{* *} \mathrm{p}<0.05,{ }^{*} \mathrm{p}<0.10$ 


\begin{tabular}{|c|c|c|c|c|c|c|}
\hline & \multicolumn{2}{|c|}{ Childcare } & \multicolumn{2}{|c|}{ Private Households } & \multicolumn{2}{|c|}{ Food Services } \\
\hline & $\begin{array}{l}\text { Median } \\
\text { Wage }\end{array}$ & $\begin{array}{l}\text { Proportion of } \\
\text { Labor Force in } \\
\text { Occupation }\end{array}$ & $\begin{array}{l}\text { Median } \\
\text { Wage }\end{array}$ & $\begin{array}{l}\text { Proportion of } \\
\text { Labor Force in } \\
\text { Occupation }\end{array}$ & $\begin{array}{l}\text { Median } \\
\text { Wage }\end{array}$ & $\begin{array}{l}\text { Proportion of } \\
\text { Labor Force in } \\
\text { Occupation }\end{array}$ \\
\hline & 1 & 2 & 3 & 4 & 5 & 6 \\
\hline Share Working Age Low-Skilled Immigrant & $\begin{array}{c}-3.671^{* * *} \\
(1.089)\end{array}$ & $\begin{array}{c}0.020 \\
(0.021)\end{array}$ & $\begin{array}{c}-0.846^{* *} \\
(0.384)\end{array}$ & $\begin{array}{c}0.044^{* * *} \\
(0.015)\end{array}$ & $\begin{array}{l}-0.549 \\
(0.476)\end{array}$ & $\begin{array}{c}0.036 \\
(0.031)\end{array}$ \\
\hline $\begin{array}{l}\text { Log Mean Income of Males with College } \\
\text { in MSA, Year }\end{array}$ & $\begin{array}{c}0.746^{* * *} \\
(0.163)\end{array}$ & $\begin{array}{l}-0.005^{*} \\
(0.003)\end{array}$ & $\begin{array}{c}0.537 * * * \\
(0.087)\end{array}$ & $\begin{array}{c}-0.006^{* *} \\
(0.003)\end{array}$ & $\begin{array}{c}0.548 * * * \\
(0.097)\end{array}$ & $\begin{array}{c}-0.014 * * * \\
(0.004)\end{array}$ \\
\hline Year Fixed Effects & Yes & Yes & Yes & Yes & Yes & Yes \\
\hline MSA Fixed Effects & Yes & Yes & Yes & Yes & Yes & Yes \\
\hline First Stage F (excluded instrument) & 12.77 & 12.77 & 12.77 & 12.77 & 12.77 & 12.77 \\
\hline $\mathrm{N}$ & 354 & 354 & 354 & 354 & 354 & 304 \\
\hline
\end{tabular}

Notes: Standard errors clustered by MSA and year. Median wages are constructed using a sample of workers, including natives, who report working more than zero hours in a typical week or worked more than zero hours in the reference week and who had positive yearly wages in the previous year. The proportion of the labor force in occupation measures the number of workers who report having the occupation divided by the total number of workers (in the person's MSA and year). ${ }^{* * *} \mathrm{p}<0.01,{ }^{* *} \mathrm{p}<0.05,{ }^{*} \mathrm{p}<0.10$ 
Table 5: Heterogeneous Responses to Immigrant Inflows

\begin{tabular}{|c|c|c|c|c|c|c|c|c|}
\hline \multirow[t]{3}{*}{ DEPENDENT VARIABLE: CHILD } & \multicolumn{2}{|c|}{ Education } & \multicolumn{2}{|c|}{ Marital Status } & \multicolumn{3}{|c|}{ Race } & \multirow[t]{2}{*}{ Full Sample } \\
\hline & College & Graduate Degree & Married & Unmarried & White & Black & Other & \\
\hline & 1 & 2 & 3 & 4 & 5 & 6 & 7 & 8 \\
\hline \multirow[t]{2}{*}{ Share Working Age Low-Skilled Immigrant } & $0.193 *$ & $0.442^{* * *}$ & $0.430 * *$ & 0.018 & $0.365 * *$ & -0.125 & -0.123 & \\
\hline & $(0.116)$ & $(0.159)$ & $(0.213)$ & $(0.017)$ & $(0.162)$ & $(0.133)$ & $(0.124)$ & \\
\hline Share Working Age Low-Skilled Immigrant & & & & & & & & $0.924 * *$ \\
\hline from High Childcare Countries & & & & & & & & $(0.374)$ \\
\hline Share Working Age Low-Skilled Immigrant & & & & & & & & 0.148 \\
\hline from Low Childcare Countries & & & & & & & & $(0.232)$ \\
\hline Mean of Dependent Variable & 0.073 & 0.075 & 0.116 & 0.006 & 0.075 & 0.055 & 0.059 & 0.073 \\
\hline $\mathrm{N}$ & 432,136 & 175,654 & 371,269 & 236,521 & 544,776 & 51,059 & 11,955 & 607,790 \\
\hline
\end{tabular}

Notes: The married sample, shown in column 3, consists of married women with a spouse present. The unmarried sample, shown in column 4, consists of all others including cohabiting, divorced, widowed, and never married women. All regressions are run using 2SLS and include the full set of controls shown in Table 2 including MSA, year, and age fixed effects. ${ }^{* * *} \mathrm{p}<0.01, * * \mathrm{p}<0.05,{ }^{*} \mathrm{p}<0.10$ 
Table 6: Labor Supply Responses to Immigrant Share

\begin{tabular}{lcccc}
\hline DEPENDENT VARIABLE: USUAL HOURS & More than 0 & 35 or more & 40 or more & 50 or more \\
\cline { 2 - 5 } PER WEEK ARE.. & 1 & 2 & 3 & 4 \\
\hline \hline Share Working Age Low-Skilled Immigrant & $-0.255^{* * *}$ & 0.139 & 0.238 & $0.782^{* *}$ \\
& $(0.094)$ & $(0.120)$ & $(0.371)$ & $(0.342)$ \\
Graduate Degree & $0.064^{* * *}$ & $0.073^{* * *}$ & $0.066^{* * *}$ & $0.059^{* * *}$ \\
& $(0.002)$ & $(0.003)$ & $(0.003)$ & $(0.003)$ \\
Married & $-0.123^{* * *}$ & $-0.229^{* * *}$ & $-0.212^{* * *}$ & $-0.076^{* * *}$ \\
& $(0.002)$ & $(0.003)$ & $(0.003)$ & $(0.003)$ \\
Black & $0.046^{* * *}$ & $0.093^{* * *}$ & $0.059^{* * *}$ & $-0.056^{* * *}$ \\
& $(0.003)$ & $(0.004)$ & $(0.008)$ & $(0.004)$ \\
Other Race & 0.003 & $0.036^{* * *}$ & $0.037^{* * *}$ & -0.004 \\
& $(0.005)$ & $(0.007)$ & $(0.006)$ & $(0.006)$ \\
Log Mean Income of Males with College & -0.032 & 0.042 & $0.143^{* * *}$ & $0.093^{* *}$ \\
in MSA, Year & $(0.021)$ & $(0.029)$ & $(0.050)$ & $(0.040)$ \\
Proportion Married in Age Group, & 0.007 & $-0.201^{* * *}$ & $-0.195^{* * *}$ & -0.026 \\
$\quad$ MSA, Year & $(0.029)$ & $(0.045)$ & $(0.047)$ & $(0.025)$ \\
Proportion Black in Age Group, & $0.151^{* * *}$ & 0.075 & 0.084 & $-0.189^{* *}$ \\
MSA, Year & $(0.050)$ & $(0.092)$ & $(0.128)$ & $(0.090)$ \\
Proportion Other Race in Age Group, & $-0.350^{* * *}$ & $-0.722^{* * *}$ & $-0.561^{* * *}$ & $0.431^{* * *}$ \\
MSA, Year & $(0.132)$ & $(0.241)$ & $(0.206)$ & $(0.112)$ \\
Age Fixed Effects & Yes & Yes & Yes & Yes \\
Year Fixed Effects & Yes & Yes & Yes & Yes \\
MSA Fixed Effects & Yes & Yes & Yes & Yes \\
Mean of Dependent Variable & & & & \\
N & 0.124 & 0.696 & 0.617 & 0.127 \\
\hline Not & 607,790 & 607,790 & 607,790 & 607,790 \\
\hline
\end{tabular}

Notes: The dependent variable in column 1 is a dummy variable equal to one if the woman works more than zero hours in a typical week, in column 2 the dependent variable equals one if the woman works at least 35 hours in a typical week, in column 3 at least 40 hours and in column 4 at least 50 hours. All regressions are run using 2SLS. 
Table 7: 2SLS Fertility and Labor Supply Regressions by Education

\begin{tabular}{|c|c|c|c|c|}
\hline \multirow{4}{*}{ DEPENDENT VARIABLE: } & \multicolumn{2}{|c|}{ College Only } & \multicolumn{2}{|c|}{ Graduate Degree } \\
\hline & Child & Usually work & Child & Usually work \\
\hline & & 50 hours plus & & 50 hours plus \\
\hline & 1 & 2 & 3 & 4 \\
\hline \multirow[t]{2}{*}{ Share Working Age Low-Skilled Immigrant } & $0.193 *$ & $0.803^{* *}$ & $0.442 * * *$ & $0.646^{* *}$ \\
\hline & $(0.116)$ & $(0.390)$ & $(0.159)$ & $(0.258)$ \\
\hline $\mathrm{N}$ & 432,136 & 432,136 & 175,654 & 175,654 \\
\hline Mean of Dependent Variable & 0.0749 & 0.164 & 0.0727 & 0.113 \\
\hline Ratio of Effect on Fertility to Effect on Work & \multicolumn{2}{|r|}{0.24} & \multicolumn{2}{|r|}{0.68} \\
\hline $\begin{array}{l}\text { Ratio of Effect on Fertility to Effect on Work } \\
\text { (adjusted by means of dependent variable) }\end{array}$ & \multicolumn{2}{|r|}{0.53} & \multicolumn{2}{|r|}{1.06} \\
\hline \multicolumn{5}{|c|}{$\begin{array}{l}\text { Notes: Regression results shown in the first two columns are constructed using a sample of women with no more } \\
\text { than a college degree while the last two columns are constructed using a sample of women with a graduate degree. } \\
\text { The ratio of the effect on fertility to the effect on work divides the estimated coefficient in the first row of column } \\
1 \text { (or column } 3 \text { ) by the estimated coefficient in column } 2 \text { (or } 4) \text {. When adjusted by the means of the dependent } \\
\text { variable, the estimated fertility coefficient is first divided by average fertility of the given sample and the estimated } \\
\text { labor supply coefficient is first divided by the mean labor supply of the given sample. For example, for the college } \\
\text { only sample, the adjusted ratio of } .53 \text { is equal to }(.193 / .0749) /(.803 / .164) \text {. All regressions are run using } 2 S L S \text { and } \\
\text { include the full set of controls shown in Table } 2 \text { including MSA, year, and age fixed effects. } * * * \mathrm{p}<0.01 \text {, ** } \\
\mathrm{p}<0.05 \text {, }^{*} \mathrm{p}<0.10 \text {. }\end{array}$} \\
\hline
\end{tabular}


Table 8: 2SLS Fertility and Labor Supply Regressions by Marital Status

\begin{tabular}{|c|c|c|c|c|}
\hline \multirow{4}{*}{ DEPENDENT VARIABLE: } & \multicolumn{2}{|c|}{ Married } & \multicolumn{2}{|c|}{ Unmarried } \\
\hline & Child & Usually work & Child & Usually work \\
\hline & \multicolumn{2}{|r|}{50 hours plus } & \multicolumn{2}{|r|}{50 hours plus } \\
\hline & 1 & 2 & 3 & 4 \\
\hline \multirow{3}{*}{$\begin{array}{l}\text { Share Working Age Low-Skilled } \\
\text { Immigrant }\end{array}$} & & & & \\
\hline & $0.430^{* *}$ & $0.526^{* * *}$ & 0.0182 & $0.930^{*}$ \\
\hline & $(0.213)$ & $(0.189)$ & $(0.0170)$ & $(0.476)$ \\
\hline $\mathrm{N}$ & 371,269 & 371,269 & 236,521 & 236,521 \\
\hline Mean of Dependent Variable & 0.116 & 0.102 & 0.00567 & 0.168 \\
\hline \multicolumn{5}{|l|}{ Ratio of Effect on Fertility to Effect on } \\
\hline Work & \multicolumn{2}{|r|}{0.82} & \multicolumn{2}{|r|}{0.02} \\
\hline Ratio of Effect on Fertility to Effect on & & & & \\
\hline $\begin{array}{l}\text { Work (adjusted by means of dependent } \\
\text { variable) }\end{array}$ & \multicolumn{2}{|r|}{0.72} & \multicolumn{2}{|r|}{0.58} \\
\hline
\end{tabular}

Notes: Regression results shown in the first two columns are constructed using a sample of married women while the last two columns are constructed using a sample of women who are not currently married (cohabiting, divorced, widowed, or never married women). The ratio of the effect on fertility to the effect on work divides the estimated coefficient in the first row of column 1 (or column 3 ) by the estimated coefficient in column 2 (or 4 ). When adjusted by the means of the dependent variable, the estimated fertility coefficient is first divided by average fertility of the given sample and the estimated labor supply coefficient is first divided by the mean labor supply of the given sample. For example, for the married sample, the adjusted ratio of .72 is equal to (.430/.116)/(.526/.102). All regressions are run using 2SLS and include the full set of controls shown in Table 2 including MSA, year, and age fixed effects. ${ }^{* * *} \mathrm{p}<0.01,{ }^{* *} \mathrm{p}<0.05,{ }^{*} \mathrm{p}<0.10$ 


\section{Appendix 1}

Table A1: Impacts of Immigration at Various Points of Wage Distribution

\begin{tabular}{lccc}
\hline & \multicolumn{3}{c}{ Log of Wages at the... } \\
& 25th Percentile & 50 th Percentile & 75th Percentile \\
& 1 & 2 & 3 \\
\hline \hline Panel A: Childcare & & & \\
Share Working Age Low-Skilled Immigrant & $-4.977^{* * *}$ & $-3.671^{* * *}$ & $-2.348^{* * *}$ \\
N & $(1.441)$ & $(1.089)$ & $(0.769)$ \\
& 354 & 354 & 354 \\
Panel B: Housekeeping & & & \\
Share Working Age Low-Skilled Immigrant & $-1.304^{* * *}$ & $-0.846^{* *}$ & $-1.506^{* * *}$ \\
& $(0.430)$ & $(0.384)$ & $(0.520)$ \\
N & 354 & 354 & 354 \\
& & & \\
Panel C: Food Services & & & -0.415 \\
Share Working Age Low-Skilled Immigrant & -0.709 & -0.549 & $(0.366)$ \\
& $(0.654)$ & $(0.476)$ & 354 \\
\hline
\end{tabular}

Notes: All of the estimates shown in this table are constructed from separate 2SLS regressions. All regressions include a control for (log) annual wage income among male college graduates as well as MSA and year fixed effects. Column 2 shows impacts of low skilled immigrant inflows on median wages of the three household services industries. Columns 1 and 3 present estimates of the effect of immigrant inflows on wages at the $25^{\text {th }}$ and $75^{\text {th }}$ percentile, respectively, in the three industries. ${ }^{* * *} \mathrm{p}<0.01,{ }^{* *} \mathrm{p}<0.05,{ }^{*} \mathrm{p}<0.10$ 
Table A2: Heterogeneous Responses to Immigrant Inflows by Education

\begin{tabular}{lcccc}
\hline & $\begin{array}{c}\text { High } \\
\text { School } \\
\text { DEPENDENT VARIABLE: CHILD }\end{array}$ & $\begin{array}{c}\text { High School } \\
\text { Degree }\end{array}$ & $\begin{array}{c}\text { College } \\
\text { Degree } \\
\end{array}$ & $\begin{array}{c}\text { Graduate } \\
\text { Degree }\end{array}$ \\
\hline \hline Share Working Age Low-Skilled Immigrant & -0.00823 & $0.0947^{* * *}$ & $0.193^{*}$ & $0.442^{* * *}$ \\
& $(0.0880)$ & $(0.0366)$ & $(0.116)$ & $(0.159)$ \\
& & & & \\
N & 220,998 & $1,502,966$ & 432,136 & 175,654 \\
Mean of Dependent Variable & 0.0592 & 0.0650 & 0.0727 & 0.0749 \\
\hline
\end{tabular}

Notes: All of the estimates shown in this table are constructed from separate 2SLS regressions. Results in the first column are constructed using a sample of women with less than a high school degree. The second column sample includes women with a high school degree and potentially some college. The third and fourth columns reproduce results shown in Table 5 for convenience. All regressions include the full set of controls shown in Table 2 including MSA, year, and age fixed effects. 


\section{Appendix 2}

High childcare countries (from lowest concentration of childcare workers to highest):

Indonesia, Brazil, Colombia, Spain, France, Argentina, Algeria, British West Indies, Ireland, Fiji, Wales, Norway, Uruguay, Peru, Chile, El Salvador, Belize/British Honduras, Sierra Leone, Liberia, Sri Lanka (Ceylon), Denmark, Honduras, Sudan, Bolivia, Guatemala, Bermuda, Cameroon, Greenland, Paraguay

\section{Low childcare countries (from lowest concentration of childcare workers to highest):}

Albania, Senegal, Tunisia, Uganda, Qatar, Yemen, PDR (South), Nepal, St. Helena and Ascension, Cyprus, United Arab Emirates, Lithuania, Zimbabwe, Latin America, ns, Saudi Arabia, Bulgaria, Yemen Arab Republic (North), Oman, Falkland Islands, Somalia, Morocco, Hungary, Vietnam, Laos, Ghana, Greece, Lebanon, Nigeria, Egypt/United Arab Rep., Yugoslavia, Turkey, Czechoslovakia, India, Syria, South Africa (Union of), China, Romania, Cuba, USSR/Russia, Western Samoa, Italy, Libya, Tanzania, Korea, Portugal, Philippines, New Zealand, Iraq, Kuwait, Jordan, Ethiopia, Thailand, Cambodia (Kampuchea), Haiti, Iran, Singapore, American Samoa, Pakistan, Israel/Palestine, Canada, Dominican Republic, Japan, Burma (Myanmar), Australia, Malaysia, Afghanistan, Latvia, Panama, Scotland, Mexico, Germany, Netherlands, Belgium, Poland, Tonga, Venezuela, Finland, Cape Verde, Switzerland, Sweden, Jamaica, Kenya, Austria, England, Ecuador, Costa Rica, Nicaragua 